Терентьєва Наталія Олександрівна

доктор педагогічних наук, доцент, професор кафедри педагогіки, психології та методики фізичного виховання Національний університет “Чернігівський колегіум” імені Т.Г. Шевченка, м. Чернігів, Україна

ORCID ID 0000-0002-3238-1608

nataterentyeva@gmail.com

\title{
ОСОБЛИВОСТІ ДИСТАНЦЙННӦ̈ ПІДГОТОВКИ МАГІСТРАНТІВ ФАКУЛЬТЕТІВ ФІЗИЧНОЇ КУЛЬТУРИ
}

\begin{abstract}
Анотація. У статті репрезентовано стан дистанційної освіти в процесі професійної підготовки магістрантів спеціальностей 017 Фізична культура і спорт та 014 Середня освіта (фізична культура) на прикладі Національного Університету “Чернігівський колегіум” імені Т.Г. Шевченка. Представлено позитивні та негативні аспекти впровадження дистанційної форми навчання для здійснення професійної підготовки майбутніх фахівців зазначених спеціальностей з урахуванням особливостей студентського контингенту та специфіки регіону. Магістранти регіону не відмовляються від традиційних форм набуття освіти, більш того, наголошують на неможливості входу до системи дистанційного навчання з прикордонних районів області (Чернігівська область межує 3 республікою Білорусь і Російською Федерацією), пропонують дублювати інформацію дистанційних курсів, розміщених на платформі друкованими (або в е-версії) матеріалами, що, 3 одного боку, спростить їм сприйняття матеріалу, а 3 іншого, частково унеможливить виконання індивідуальних та / або групових завдань окремими студентами. Дані анкетування студентівмагістрантів 2017 і 2018 років випуску зазначених спеціальностей свідчать, що вбачають недоцільним повний перехід на дистанційну освіту $70 \%$ респондентів, доцільним частковий перехід $-81 \%$, відмовляються від використання платформи - $8 \%$, висловлюють побоювання, що не зможуть опанувати навчальну дисципліну, розміщену на платформі, - 15\%. Виокремлено перспективні можливості розвитку дистанційної освіти для окреслених спеціальностей 3 урахуванням особливостей цільової аудиторії, зокрема, зростання кількості працюючих магістрантів та магістрантів, які отримують додаткову вищу освіту, майбутніх фахівців зі столичних регіонів, які прагнуть отримати недорогу додаткову вищу освіту (у регіонах) засобами дистанційного навчання; зростанням кількості магістрантів зазначених спеціальностей, які перебувають на службі у Збройних Силах України та силових структурах. Наголошено на необхідності врахування особливостей регіону та ментальності його населення при переході на дистанційну освіту.
\end{abstract}

Ключові слова: дистанційне навчання; дистанційна освіта; електронний навчальний комплекс; фізична культура і спорт; платформа Moodle; регіональні особливості.

\section{1. ВСТУП}

Постановка проблеми. Дистанційна (дистантна) освіта відповідно до вітчизняних унормовуючих документів - це "можливість навчатися та отримувати необхідні знання віддалено від навчального закладу в будь-який зручний час” [1], регульована Положенням про дистанційне навчання (2013 із змінами і доповненнями) [2], [3], Концепцією розвитку дистанційної освіти в Україні (2000) [4], Стратегією розвитку інформаційного суспільства в Україні (2013) [5]. Відповідно, однією з форм отримання освіти на основі виключно інформаційно-комунікаційних технологій $є$ електронна освіта, яка набуває активного поширення серед усіх верств населення завдяки наявній інформаційній інфраструктурі (“сукупність різноманітних інформаційних (автоматизованих) систем, інформаційних ресурсів, телекомунікаційних мереж і каналів передачі даних, засобів комунікацій i управління інформаційними потоками, а також організаційно-технічних структур, механізмів, що забезпечують їх функціонування" [5]). Серед низки пріоритетних заходів, спрямованих на реалізацію е-освіти [5] виокремимо забезпечення всіх закладів освіти широкосмуговим доступом до міжнародних науково-освітніх мереж та Інтернету. Практично 
всі заклади вищої освіти здійснюють реалізують електронну освіту через дистанційні курси, розміщені на відповідних програмних платформах дистанційного навчання.

Заклади вищої освіти грунтують можливості дистанційної освіти (навчання) переважно на одній з таких платформ як MOODLE та/ або E-LEARNing. У закладах вищої освіти (3BO), які здійснюють підготовку майбутніх фахівців педагогічного профілю, платформа MOODLE (модульне об'єктно-орієнтоване середовище дистанційного навчання) проходила апробування й набула більшого розповсюдження, оскільки є безкоштовною. Тому для відповідних педагогічних напрямів підготовки можливості саме цієї платформи покликані забезпечити так званий “універсальний дизайн у сфері освіти - дизайн предметів, навколишнього середовища, освітніх програм та послуг, що забезпечує їх максимальну придатність для використання всіма особами без необхідної адаптації чи спеціального дизайну" [6]. Виходячи з цього твердження, розглянемо можливості для забезпечення здійснення дистанційного навчання в умовах професійної підготовки майбутніх фахівців спеціальностей та спеціалізацій, які працюватимуть на посадах вчителя фізичної культури у закладах освіти, тренера, інструктора тощо.

Аналіз останніх досліджень і публікацій. Переваги та доцільність створення електронних / мультимедійних комплексів для забезпечення ними вітчизняних студентів різних галузей, напрямів, спеціальностей $є$ предметом дослідження науково-методичного характеру фахівців різних сфер: соціономічної, техніко-технологічної, гуманітарної, військової тощо.

Фахові видання та збірники матеріалів конференцій за останні 20 років репрезентували наукові напрацювання як здобувачів наукових ступенів, так і науковців зі значним досвідом роботи, а також напрацювання шкільних педагогів. Ми ж зупинимося на працях, у яких окреслено основні положення дистанційної освіти в контексті критичного аналізу іiі запровадження для окремих спеціальностей та відображено окремий досвід впровадження дистанційної освіти для студентів - майбутніх фахівців з фізичного виховання, фізичної культури та спорту.

Зокрема, у праці [7] доведено, що електронне навчання студента є втричі дешевшим за денне (стаціонарне) і, відповідно, в умовах недофінансування закладів вищої освіти є більш доцільним і має набути повноцінного впровадження. Наголошено, що урядова політика багатьох країн проголосила дистанційну освіту пріоритетним напрямом освітньої політики 3 відповідним фінансуванням, зокрема для осіб з особливими потребами. Імпонує окреслення об'єктивних чинників, які гальмують масове впровадження дистанційної освіти в Україні. Окреслюючи підходи до впровадження системи дистанційного навчання [8], наголошено на покликанні дистанційного навчання розв'язувати специфічні завдання, зокрема впровадження нових педагогічних технологіий навчання; застосування засобів телекомунікаційного зв'язку; розвитку творчої складової освіти; створення віртуального інформаційно-освітнього середовища тощо.

Щодо використання дистанційного навчання у підготовці фахівців з фізичної культури i спорту [9] окреслено окремі технології (кейс, ТВ, мережеві), методи (асинхронний i синхронний), засоби (технічні і програмні) дистанційного навчання; переваги та недоліки дистанційного навчання, репрезентовано досвід університету щодо стажування викладачів 3 курсу “Технології дистанційного навчання онлайн навчання” тощо. Частково репрезентовано особливості змішаної форми дистанційного навчання для студентів спеціальності “Фізичне виховання і спорт" [10].

У цілому в наукових розвідках окреслено загальні питання інформатизації професійної освіти майбутніх фахівців сфери фізичного виховання і спорту та майбутніх учителів фізичної культури [11] - [18]. В Україні репрезентують науково-практичні дослідження 3 окреслених питань такі видання, як “Інформаційні технології і засоби навчання" [19], "Науково-методичні основи використання інформаційних технологій в галузі фізичної культури та спорту" [20], Наукові часописи та Вісники університетів Серії "Фізичне виховання та спорт” і “Педагогічні науки. Фізичне виховання та спорт” та інші. За даними, 
оголошеним на Семінарі, присвяченому питанням Баз даних (EBSCO) від 28 березня 2018 року (м. Київ), кількість посилань за пошуком “Дистанційна освіта / Дистанційне навчання” перевищує 42 тис. (О.В. Васильєв).

Мета статті полягає в окресленні регіональних особливостей професійної підготовки магістрантів - майбутніх фахівців спеціальностей “Фізична культура і спорт" i “Середня освіта (фізична культура)” в умовах вітчизняної педагогічної університетської освіти (на прикладі Чернігівського регіону).

\section{2. МЕТОДИ ДОСЛІДЖЕННЯ}

Для окреслення реальних можливостей та перспектив дистанційної освіти для магістрантів спеціальностей “Фізична культура i спорт" i "Середня освіта (фізична культура)” в умовах 3ВО в перехідний період між педагогічним університетом та класичним застосовано комплекс методів: теоретичні - загальнонаукові (для обгрунтування вихідних теоретичних позицій), конкретно-наукові: структурний (для виокремлення й окреслення особливостей дистанційної освіти для магістрантів відповідних спеціальностей) і проблемнотематичний (для виокремлення реальних та перспективних можливостей); емпіричні контент-аналіз (для дослідження суб'єктивних оцінок та окреслення регіональних особливостей професійної підготовки майбутніх фахівців в сучасних умовах реалізації дистанційної освіти).

\section{3. РЕЗУЛЬТАТИ ДОСЛІДЖЕННЯ}

Підготовку фахівців вищої кваліфікації у Чернігівській області здійснюють Національний університет “Чернігівський колегіум” імені Т.Г. Шевченка (до 2017 року Чернігівський національний педагогічний університет імені Т.Г. Шевченка); Чернігівський національний технологічний університет; Академія державної пенітенціарної служби України; Ніжинський державний університет імені Миколи Гоголя. Підготовку магістрантів спеціальностей “Фізична культура i спорт" i “Середня освіта (фізична культура)" у Чернігівському регіоні здійснює лише Національний університет "Чернігівський колегіум" імені Т.Г. Шевченка.

Магістрантами факультету Фізичне виховання Національного університету “Чернігівський колегіум” імені Т.Г. Шевченка (2017-2018 н.р.) вивчаються такі навчальні дисципліни (подано в алфавітному порядку):

2 рік навчання - Акмеологія особистості (з Конфліктологією); Індивідуальний розвиток людини з основами генетики; Комп'ютерні технології; Менеджмент в освіті, фізичному вихованні і спорті; Методика навчання основ здоров'я; Моніторинг та діагностика; Неолімпійські види спорту; Основи наукової комунікації іноземною мовою; Педагогіка i психологія дітей дошкільного віку; Побудова фітнес-технологій; Рекреаційні види спорту; Силові види спорту; Спортивно-педагогічне удосконалення; Сучасні педагогічні технології (у фізичному вихованні дітей дошкільного віку); Теорія і методика викладання (хореографії 3 ЗНЗ); Теорія індивідуального здоров'язбереження; Теорія фізичної культури і спорту; Технологія підготовки кваліфікаційних робіт; Фізіологічні основи адаптації до м'язової діяльності;

1 рік навчання - Адаптивна фізична культура; Акмеологія особистості; Діагностика та прогнозування у спортивній діяльності; Актуальні питання та основи адаптації в теорії фізичної культури та спорті; Інноваційні технології в освіті; Композиція і постановка танцю; Масовий і олімпійський спорт; Методика викладання фізичного виховання у вищій школі; Методика побудови навчального процесу спортсменів різної кваліфікації (Методика спортивно-масової роботи); Методологія викладання фахових дисциплін в галузі фізичного виховання і спорту; Методологія науково-дослідної роботи; Олімпійські і професійні та 
масові види спорту; Педагогіка і психологія вищої школи; Правові основи діяльності навчальних закладів різного типу; Спортивно-педагогічне удосконалення; Теорія і методика тренувального процесу в різних видах спорту; Філософія вищої школи.

Виходячи навіть із назв навчальних дисциплін легко зробити висновок про перехідність навчальних планів між підготовкою фахівців в умовах педагогічного та класичного університету. Викладачами факультету розроблено та розміщено на платформі Moodle дисципліни відповідно до попередніх навчальних планів. Дисципліни магістерського рівня переважно закріплено за кафедрами педагогіки, психології та методики фізичного виховання (на цій кафедрі працює автор статті) та біологічних основ фізичного виховання, здоров'я та спорту, які мають переважно теоретико-професійне спрямування [21]. Відповідно діяльність викладачів кафедри педагогіки, психології та методики фізичного виховання переважно спрямовано на забезпечення індивідуальної траєкторії розвитку магістрантів - майбутніх фахівців у сфері фізичного виховання та спорту.

Для кафедр суто спортивного профілю, які забезпечують підготовку фахівців 3 конкретного виду спорту, притаманна інша ситуація - не використання можливостей платформи для дистанційного навчання. Спортивні кафедри працюють зі студентами переважно в режимі персональної співпраці без забезпечення дистанційної складової навчальних дисциплін [21].

ЕНК, розміщені на платформі Moodle, мають стандартні компоненти: Загальна інформація про курс (робоча програма, тематичний план, критерії оцінювання, друковані та інтернет-джерела у форматі веб-сторінки, термінологічний словник у форматі глосарію, оголошення у форматі форуму), теоретичний матеріал (електронні навчальні матеріали у вигляді електронного посібника з гіперпосиланнями, додаткові мультимедійні навчальнометодичні матеріали, методичні рекомендації, тести), практичні / семінарські заняття / лабораторні роботи (окремі ресурси для кожного заняття), завдання для самостійної роботи (методичні рекомендації та окремі ресурси), модульний контроль (контрольні запитання та тести), підсумкова атестація.

Для дисциплін на кшталт “Спортивно-педагогічне удосконалення”, “Рекреаційні види спорту”, “Композиція і постановка танцю”, “Адаптивна фізична культура”, “Силові види спорту”, “Неолімпійські види спорту”, “Побудова фітнес-технологій”, де практичні заняття відбуваються в спортивних комплексах, доцільним $є$ розміщення інформації суто ознайомлювального характеру з додатковим унаочненням у вигляді супроводжувальних відеоматеріалів (наприклад, фрагменти тренувань та змагань, навчальні відеокурситренування, коментарі фахівців, відеозвіти тощо). Зрозуміло, що тестові завдання (складені навіть відповідно до таксономії Б. Блума) $\epsilon$ некоректними в якості модульного та / або підсумкового контролю, навіть якщо будуть супроводжуватися відеозвітом.

Зазначимо, що в цілому в Україні спостерігається ситуація, коли окремі заклади вищої освіти активно використовують платформу Moodle для забезпечення дистанційної складової підготовки майбутніх фахівців з фізичного виховання, зокрема Київський університет імені Бориса Грінченка, Запорізький технічний університет, Національний педагогічний університет імені М.П.Драгоманова, Національний університет біоресурсів та природокористування України, Кіровоградський державний педагогічний університет імені Володимира Винниченка, Тернопільський національний педагогічний університет імені Володимира Гнатюка, Харківський національний педагогічний університет імені Григорія Сковороди, Чернівецький національний університет імені Юрія Федьковича та ін. Проте не всі заклади вищої та післядипломної освіти розміщують дистанційні курси для студентів спеціальностей “Фізична культура і спорт” і “Середня освіта (фізична культура)” та вчителів фізичної культури. Це частково пов’язано зі специфікою спеціальностей, проте доволі часто з нерозумінням викладацьким складом реальних можливостей дистанційної освіти, особливо для студентів, які перебувають на зборах у тренувальних таборах, змаганнях, здійснюють тренерську діяльність в інших регіонах тощо. 
Заклади післядипломної педагогічної освіти пропонують для вчителів фізичної культури дистанційні курси, покликані підвищити рівень кваліфікації вчителів фізичної культури через, зокрема, самостійне вивчення та активне впровадження нових прийомів $\mathrm{i}$ методів навчання, нових форм, перспективних технологій, розширення методичного діапазону знань, збагачення творчого потенціалу, забезпечення інформацією [22]. Проте, незважаючи на задекларовану дистанційність курсів, навчання передбачає три етапи, два 3 яких - очні.

Дистанційні курси для школярів [23], [24] передбачають перелік контрольних навчальних нормативів та вимог з фізичної культури, окреслення загальних особливостей вивчення дисципліни та теоретичні відомості про окремі види спорту. Частково в їх розробці в межах завдань виробничої практики беруть участь і студенти спеціальностей "Фізична культура і спорт” і “Середня освіта (фізична культура)". Незважаючи на намагання окремих закладів освіти не столичного регіону створювати дистанційні курси, активність споживачів цих послуг залишається вкрай низькою, на відміну від столичного. Ми свідомо не вказували назви закладів освіти, оскільки розуміємо усі складнощі та дискурсивні моменти організації дистанційної освіти в цілому та впровадження окремих елементів дистанційного навчання для спеціальностей, пов'язаних із фізичною культурою, фізичним вихованням та спортом.

Авторськими навчальними курсами є “Менеджмент в освіті, фізичному вихованні та спорті”, який викладається студентам факультету Фізичне виховання протягом останніх двох років, та “Акмеологія особистості”. Доцільність їх запровадження обумовлена специфікою регіону - переважна більшість студентів-магістрантів і випускників факультету посідають керівні посади (наприклад, випуск 2017 року - 20 осіб з 24, випуск 2018 року - 18 осіб з 28). Окремі завдання, адаптовані для дистанційного навчання магістрантів, частково репрезентовано у наукових авторських розвідках [25, с. 37-44], [26].

При вивченні навчальної дисципліни “Акмеологія особистості" доцільним є посилання магістрантів на офіційний сайт Української Академії Акмеології [27], де представлено, зокрема, матеріали журналу “Акмеологія в Україні: теорія і практика", матеріали міжнародних ("Сучасні стратегії педагогічної освіти у вимірах розбудови суспільства сталого розвитку та міжкультурної інтеграції”, “Акмеологія: наука XXI століття”, “Сучасна наука та освіта: самовизначення особистості в контексті євроінтеграції”, “Освіта як фактор формування людського капіталу та економічного розвитку”) та всеукраїнських (“Становлення і розвиток акмеології: теоретичні і прикладні аспекти”) науково-практичних конференцій. Наукові розробки провідних фахівців-акмеологів стануть у нагоді магістрантам для вибудови та/або коригування траєкторії власного професійного та особистісного розвитку.

Зазначені навчальні дисципліни передбачають в якості підсумкової атестації виконання проектів. На жаль, можливості платформи не завжди розраховані на одночасне розміщення магістрантами проектних робіт. Перспективним вбачаємо оновлення та адаптацію розроблених дистанційних курсів навчальних дисциплін для студентів-магістрантів, оскільки модернізуються навчальні плани, зростає кількість працюючих магістрантів та магістрантів, які отримують додаткову вищу освіту, майбутніх фахівців зі столичних регіонів, які прагнуть отримати недорогу додаткову вищу освіту (у регіонах) засобами дистанційного навчання.

Зазначимо, що магістранти не відмовляються від традиційних форм набуття освіти, більш того, наголошують на неможливості входу до системи дистанційного навчання 3 прикордонних районів області (Чернігівська область межує 3 республікою Білорусь $\mathrm{i}$ Російською Федерацією), що, безперечно, необхідно враховувати при побудові освітнього процесу. Вони пропонують дублювати інформацію дистанційних курсів, розміщених на платформі друкованими (або в е-версії) матеріалами, що, з одного боку, спростить їм сприйняття матеріалу, а з іншого, частково унеможливить виконання індивідуальних та / або групових завдань окремими студентами.

Особливостями Чернігівського регіону, які впливають на побудову освітнього процесу, зокрема дистанційної освіти, виокремлюємо: 
- прикордонний регіон (студенти з районів, які межують з Російською Федерацією та Республікою Білорусь, мають труднощі входу в систему дистанційного навчання, що пов'язано зі слабкою інтернет-мережею, що пов'язано з межуванням 3 країноюагресором);

- пасивність населення (мешканці регіону в силу історичних традицій виявляють інертність до нововведень, обгрунтовуючи небажання впровадження інновацій як збереження традицій);

- одночасне усвідомлення відсутності конкуренції з боку інших ЗВО регіону у підготовці фахівців окреслених спеціальностей та близькість до столичного регіону із ЗВО, які мають вищі рейтингові позиції (викладачі регіону демонструють позицію неможливості конкуренції 3 закладами столичного регіону, що й спричиняє небажання нового виду діяльності);

- превалювання видів спорту, які мають підтримку на рівні владних та університетських структур (волейбол чоловічий і жіночий) і меценатів (різні види боротьби, біатлон, бокс, панкратіон, настільний теніс (для кадетів) тощо).

За даними анкетування студентів-магістрантів 2017 і 2018 років випуску спеціальностей “Фізична культура і спорт” і “Середня освіта (фізична культура)” зазначимо, що вбачають недоцільним повний перехід на дистанційну освіту $70 \%$ респондентів, вбачають доцільним частковий перехід - 81\%, відмовляються від використання платформи $8 \%$, висловлюють побоювання, що не зможуть опанувати навчальну дисципліну, розміщену на платформі, $-15 \%$.

324 магістрантів 2017 року випуску на 2 році навчання 20 працювало на керівних посадах і усвідомлювало переваги поєднання дистанційної та традиційної освіти, виходячи 3 досвіду роботу; проте магістранти 2018 року випуску денної форми навчання (спортсмени вищої кваліфікації, вчителі та робітники не за фахом) у переважній більшості висловили побоювання, що не зможуть опанувати дистанційні курси у визначені терміни або через відсутність доступу до дистанційного навчання університету (прикордонний регіон), або у зв’язку з перебуванням на тренувальних зборах та змаганнях, або через постійно змінюваний графік роботи. 36 студентів заочної форми навчання 2018 року випуску бажання до навчання за дистанційною форму не виявив ніхто, обгрунтовуючи це тим, що в змозі самостійно опанувати навчальну літературу, але бажаним є спілкування з викладачами для можливості обговорення окремих дискурсивних питань (незважаючи на такий склад магістрантів: параолімпійський чемпіон (футбол), гравець команди вищої ліги (баскетбол), тренери силових видів спорту (і міжнародного класу), тренери дитячих команд).

Тому для магістрантів факультетів фізичного виховання доцільним вбачаємо поєднання дистанційної освіти та спортивно-ігрової діяльності з практичною підготовкою (поєднання синхронного й асинхронного навчання). Отримані дані свідчать про необхідність врахування специфіки спеціальностей, оскільки кардинально відрізняються від даних, характерних для студентів природничо-математичної, соціономічної, техніко-технічної, соціокультурної та гуманітарної сфер діяльності, і $є$ наближеними до даних підготовки фахівців військових та силових структур, оскільки щорічно збільшується кількість магістрантів факультету фізичного виховання Національного університету "Чернігівський колегіум” імені Т.Г. Шевченка, які перебувають н службі в силових та військових структурах країни.

\section{4. ВИСНОВКИ ТА ПЕРСПЕКТИВИ ПОДАЛЬШИХ ДОСЛІДЖЕНЬ.}

На наше переконання, у професійній підготовці магістрантів спеціальностей “Фізична культура і спорт” і “Середня освіта (фізична культура)" варто враховувати той факт, що наявні можливості будь-якої платформи, у тому числі і платформи Moodle не в змозі забезпечити спортсменам і вчителям фізичної культури реальні умови тренування та 
спортивно-педагогічного вдосконалення у спортивних та спеціалізованих залах, на ігрових та змагальних майданчиках, стадіонах, басейні, кортах, інших спортивних комплексах та рекреаційних зонах. Тому традиційний компонент підготовки залишається провідним при спортивних тренуваннях. Навчальними планами передбачено вивчення таких навчальних дисциплін, які доцільно розробляти і розміщувати саме на платформах дистанційного навчання, оскільки це дає змогу магістрантам, які перебувають на зборах, змаганнях, працюють за фахом у будь-який зручний для них час опановувати відповідні навчальні дисципліни. Маючи обмаль часу, магістранти мають нагоду отримати квінтесенцію змістового наповнення навчальної дисципліни, зорієнтуватись та вибудувати оптимальну для себе траєкторію іiі опанування з урахуванням бажаного рівня (від А до F), що й визначатиме обсяг та ретельність виконуваних завдань 3 кожної дисципліни. Проте зауважимо, що віртуальна підготовка до змагань допоки не дає перемог, так само як і відірваність теоретичного матеріалу від реальних ситуацій спортивно-тренувального процесу.

Важливим фактором переходу на дистанційну форму $є$ сприйняття iї доцільності викладачами і студентами закладів освіти з урахуванням регіональних особливостей, що безпосередньо впливає на швидкість переходу та якість навчальних дисциплін. Це, зокрема, пасивність та усталеність традицій, усвідомлення регіональної винятковості, специфіка кордону з країною-агресором тощо.

Вбачаємо за доцільне дослідити особливості впровадження й застосування дистанційної освіти, зокрема й у змішаній формі, або іiї окремих елементів 3 урахуванням специфіки регіону, особливостей ментальності населення, чисельності населення, освітянських традицій тощо.

\section{СПИСОК ВИКОРИСТАНИХ ДЖЕРЕЛ}

[1] Дистанційна освіта. [Електронний ресурс]. Доступно: https://mon.gov.ua/ua/osvita/visha-osvita/distancijnaosvita Дата звернення: Трав. 23, 2018.

[2] Положення про дистанційне навчання. [Електронний ресурс]. Доступно: http://zakon2.rada.gov.ua/laws/show/z0703-13 Дата звернення: Трав. 23, 2018.

[3] Зміни до Положення про дистанційне навчання. [Електронний ресурс]. Доступно: http://zakon3.rada.gov.ua/laws/show/z0923-15 Дата звернення: Трав. 23, 2018.

[4] Концепція розвитку дистанційної освіти в Україні. [Електронний ресурс]. Доступно: http://www.osvita.org.ua/distance/pravo/00.html Дата звернення: Трав. 23, 2018.

[5] Стратегія розвитку інформаційного суспільства в Україні. [Електронний ресурс]. Доступно: http://zakon2.rada.gov.ua/laws/show/386-2013-p Дата звернення: Трав. 23, 2018.

[6] Закон України Про освіту. [Електронний ресурс]. Доступно: http://zakon3.rada.gov.ua/laws/show/2145-19 Дата звернення: Трав. 23, 2018.

[7] Н. Самолюк, М. Швець. Актуальність і проблемність дистанційного навчання. Нова педагогічна думка. № 1.1 , с. 193-201, 2013.

[8] I. О. Романенко. Підходи до впровадження системи дистанційного навчання у Збройних Силах України. Системи обробки інформащиї. Випуск 9 (49). с. 130-135, 2005. Дата звернення: Трав. 25, 2018.

[9] Г. А. Шандригось, В. І. Шандригось, П. І. Ладика. Дистанційне навчання в системі підготовки фахівців 3 фізичної культури і спорту. Науковий часопис НПУ імені М. П. Драгоманова. Випуск 5К(61), с. 270-273, 2015. Дата звернення: Трав. 25, 2018.

[10] Н. Ю. Борейко, Л. Л. Азаренкова. Використання змішаної форми дистанційного навчання на спеціальності “Фізична культура і спорт”. Науково-методичні основи використання інформаційних технологій в галузі фізичної культури та спорту. № 1, с. 16-19, 2017.

[11] О. В. Басенко. Організація дистанційного навчання студентів ВНЗ спортивного профілю засобами інформаційно-комунікаційних технологій. Науковий часопис Національного педагогічного університету імені М. П. Драгоманова. 11 (66)15, с. 12-16, 2015.

[12] Н. О. Бєлікова. Прикладні аспекти використання інформаційно-комунікаційних технологій у професійній підготовці майбутніх фахівців з фізичного виховання та спорту. Вісник Чернігівського національного педагогічного університету. Сер.: Педагогічні науки. Фізичне виховання та спорт. Вип. 118(2), с. 21-24. 2014.

[13] Ю. В. Драгнєв. Інформатизація професійної освіти майбутнього вчителя фізичної культури. Педагогіка, психологія та медико-біологічні проблеми фізичного виховання і спорту. № 2, с. 33-35, 2012.

[14] Р. В. Клопов. Інформатизація вищої фізкультурної освіти. Теорія та методика фізичного виховання. № 4, c. 3-7, 2007. 
[15] І. В. Ляшенко. Перспективи розвитку дистанційного навчання у вищій школі. Народна освіта. Вип. 1(25), 2015. [Електронний ресурс]. Доступно: https://www.narodnaosvita.kiev.ua/?page_id=2682 Дата звернення: Трав. 25, 2018.

[16] О. В. Отравенко. Вплив сучасних інформаційних технологій на якість професійної підготовки майбутніх учителів фізичної культури. Науково-методичні основи використання інформаційних технологій в галузі фізичної культури та спорту. № 2, с. 70-73, 2018.

[17] О. М. Самойленко, I. В. Бацуровська, О. О. Самойленко, Н. А. Доценко. Упровадження моделі підготовки магістрантів до освітньо-наукової діяльності в умовах масових відкритих дистанційних курсів. Інформаційні технологї та засоби навчання. т. 64, № 2, с. 197-220. [Електронний ресурс]. Доступно: https://journal.iitta.gov.ua/index.php/itlt/issue/view/93/showToc Дата звернення: Трав. $25,2018$.

[18] А. В. Сущенко. Інформаційно-комунікаційні технології і засоби навчання в професійній підготовці майбутніх фахівців фізичного виховання і спорту. Вісник Запорізького національного університету. Серія «Фізичне виховання і спорт». № 1 (7), с. 104-111, 2012.

[19] Інформачійні технологї $і$ засоби навчання. Теорія, методика і практика використання IКТ в освіті. [Електронний ресурс]. Доступно: https://journal.iitta.gov.ua/index.php/itlt/index Дата звернення: Трав. 20, 2018.

[20] Науково-методичні основи використання інформачійних технологій в галузі фізичної культури та cnopmy. [Електронний ресурс]. Доступно: http://journals.uran.ua/itfcs Дата звернення: Трав. 20, 2018.

[21] Дистанційне навчання ЧНПУ. [Електронний ресурс]. Доступно: https://moodle.chnpu.edu.ua/course/index.php?categoryid=43 Дата звернення: Трав. 20, 2018.

[22] Вчителі фізичної культури. Комунальний навчальний заклад Київської обласної ради “Київський обласний інститут післядипломної освіти педагогічних кадрів”. [Електронний ресурс]. Доступно: https://www.xn--80aamewp7k6b.com.ua/karta-sajtu-2/navchalno-metodychna-robota/dystantsijna-formanavchannya/dystantsijni-kursy/vchyteli-fizychnoyi-kultury/ Дата звернення: Трав. 28, 2018.

[23] Фізична культура (дистанційний курс). Мукачівська ЗОШ I-ІІІ ст. № 20 ім. О. Духновича. [Електронний pecypc]. Доступно: http://20zoshmk.at.ua/load/dlja_uchniv/distancijne_navchannja/fizichna_kultura/23-1-0-116 Дата звернення: Трав. 28, 2018.

[24] Фізична культура. Дистанційне навчання. Білогірський НВК. [Електронний ресурс]. Доступно: https://sites.google.com/site/pupilnvk/11-klas/fizicna-kultura Дата звернення: Трав. 28, 2018.

[25] Н. О. Терентьєва. Формування нового мислення в закладах освіти: навч.-метод. посібник. Черкаси: ФОП Чабаненко Ю.А., 2018.

[26] Н. О. Терентьєва. Проектування навчальної дисципліни "Менеджмент в освіті, фізичному вихованні i спорті" для студентів магістратури. Вісник Чернігівського національного педагогічного університету імені Т.Г. Шевченка. Серія Педагогічні науки. Вип. 144, с. 302-306, 2017.

[27] Українська Академія Акмеології. Всеукраїнська громадська організація. [Електронний ресурс]. Доступно: http://acmeology.org.uа Дата звернення: Трав. 20, 2018.

Матеріал надійшов до редакиії 23.07.2018 p.

\title{
ОСОБЕННОСТИ ДИСТАНЦИОННОЙ ПОДГОТОВКИ МАГИСТРАНТОВ ФАКУЛЬТЕТА ФИЗИЧЕСКОЙ КУЛЬТУРЫ
}

\author{
Терентьева Наталия Александровна \\ доктор педагогических наук, доцент, \\ профессор кафедры педагогики, психологии и методики физического воспитания \\ Национальный университет "Черниговский коллегиум" имени Т.Г. Шевченко, г. Чернигов, Украина \\ ORCID ID 0000-0002-3238-1608 \\ nataterentyeva@gmail.com
}

Аннотация. В статье представлено состояние дистанционного образования в процессе профессиональной подготовки магистрантов специальностей 017 Физическая культура и спорт и 014 Среднее образование (физическая культура) на примере Национального Университета “Черниговский коллегиум" имени Т.Г. Шевченко. Очерчены положительные и отрицательные аспекты внедрения дистанционной формы обучения для осуществления профессиональной подготовки будущих специалистов указанных специальностей с учетом особенностей студенческого контингента и специфики региона. Магистранты региона не отказываются от традиционных форм получения образования, более того, акцентируют внимание на невозможности входа в систему дистанционного обучения с приграничных районов области (Черниговская область граничит с Республикой Беларусь и Российской Федерацией), предлагают дублировать информацию дистанционных курсов печатными (или в е-версии) материалами, что, с одной стороны, упростит им восприятие материала, а с другой, частично сделает невозможным выполнение индивидуальных и/или групповых заданий отдельными студентами. Данные анкетирования студентов-магистрантов 2017 и 2018 годов выпуска названных специальностей 
свидетельствуют о том, что считают нецелесообразным полный переход на дистанционное образование $70 \%$ респондентов, целесообразным частичный переход - $81 \%$, отказываются от использования платформы - $8 \%$, высказывают боязнь невозможности усвоения материала, размещенного на платформе, - 15\%. Представлены перспективные возможности развития дистанционного образования для определенных специальностей с учетом особенностей целевой аудитории, в частности увеличение количества работающих магистрантов и магистрантов, получающих дополнительное высшее образование, будущих специалистов из столичных регионов, которые стремятся получить недорогое высшее образование (в регионах) посредством дистанционного обучения, количества магистрантов указанных специальностей, находящихся на службе в Вооруженных Силах Украины и силовых структурах. Отмечена необходимость учета особенностей региона и ментальности населения при переходе на дистанционное образование.

Ключевые слова: дистанционное обучение; дистанционное образование; электронный учебный комплекс; физическая культура и спорт; платформа Moodle; региональные особенности.

\title{
FEATURES OF DISTANCE EDUCATION FOR MASTERS OF PHYSICAL CULTURE FACULTIES
}

\author{
Nataliia O. Terentieva \\ Doctor of Pedagogical Sciences, Associate Professor, \\ Professor of Pedagogy, Psychology and Methods of Physical Education Department \\ National University "Chernihiv Collegium" named after T. G. Shevchenko, Chernihiv, Ukraine \\ ORCID ID 0000-0002-3238-1608 \\ nataterentyeva@gmail.com
}

\begin{abstract}
The article presents the state of distance education for the professional training of graduate students in specialties 017 Physical culture and sports and 014 Secondary education (physical culture) on the example of the T.G. Shevchenko National University "Chernihiv collegium". Positive and negative aspects of introduction of distance learning for the purpose of professional training of future specialists of these specialties are presented, taking into account the characteristics of the student contingent and Chernihiv region specifics. Masters students of the region do not refuse traditional forms of education, moreover, they emphasize the impossibility of entering the system of distance learning from the border regions of the region (Chernihiv region borders with the Republic of Belarus and the Russian Federation), offer to duplicate the information of distance courses placed on the platform printed (or e-versions) materials that, on the one hand, will facilitate their perception of the material, and on the other hand, will partially make it impossible for individual students and / or group tasks to be performed. The data of questioning of graduate students $2017-2018$ of these specialties indicate that it is inappropriate to see a complete transition to distance education of $70 \%$ of respondents, an appropriate partial transition $-81 \%$, refuse to use platforms $-8 \%$, express fears that they will not be able to master the discipline, located on the platform - $15 \%$. The perspective opportunities of the distance education development for the specified specialties are singled out, considering the characteristics of the target audience, in particular, the growth of the number of working masters and graduate students who receive additional higher education, future specialists from the metropolitan regions, who seek to obtain an inexpensive additional higher education (in the regions) means of distance learning, an increase in the number of graduates of these specialties who are in service in the Armed Forces of Ukraine and law enforcement agencies. The necessity of considering the features of the region and the mentality of the population during the transition to the distance education is emphasized.
\end{abstract}

Keywords: distance learning; distance education; electronic learning complex; physical culture and sport; Moodle platform, regional peculiarities.

\section{REFERENCES (TRANSLATED AND TRANSLITERATED)}

[1] Distance education. [online]. Available: https://mon.gov.ua/ua/osvita/visha-osvita/distancijna-osvita. Accessed on: May 23, 2018. (in Ukrainian)

[2] Regulations on Distance Learning. [online]. Available: http://zakon2.rada.gov.ua/laws/show/z0703-13 Accessed on: May 23, 2018. (in Ukrainian)

[3] Changes to the Distance Learning Regulations. [online]. Available: http://zakon3.rada.gov.ua/laws/show/z0923-15 Accessed on: May 23, 2018. (in Ukrainian)

[4] Concept of development of distance education in Ukraine. [online]. Available: http://www.osvita.org.ua/distance/pravo/00.html Accessed on: May 23, 2018. (in Ukrainian)

[5] Strategy of the Information Society Development in Ukraine. [online]. Available: http://zakon2.rada.gov.ua/laws/show/386-2013-p Accessed on: May 23, 2018. (in Ukrainian) 
[6] Law of Ukraine on Education. [online]. Available: http://zakon3.rada.gov.ua/laws/show/2145-19 Accessed on: May 23, 2018. (in Ukrainian)

[7] N. Samoluk, M. Shvets. Actuality and problem of distance learning. Nova pedagogichna dumka. № 1.1, p. 193201, 2013. (in Ukrainian)

[8] I. O. Romanenko. Approaches to implementation of the distance education system in the Armed Forces of Ukraine. Systemy obrobky informatsii. Vol. 9(49). p. 130-135, 2005. (in Ukrainian)

[9] G. A. Shandrygos', V. I. Shandrygos', P. I. Ladyka. Distance education in the system of training specialists in physical culture and sports. Naukoviy chasopis NPU imeni M. P. Dragomanova. Vol. 5K(61), p. 270-273, 2015. (in Ukrainian)

[10] N. Yu. Boreyko, L. L. Azarenkova. Use of the mixed form of distance learning on the specialty "Physical Culture and Sport". Naukovo-metodychni osnovy vykorystannia informatsiinyh technologii $v$ galuzi physychnoi cultury $i$ sporty. № 1, p. 16-19, 2017. (in Ukrainian)

[11] O. V. Basenko. Organization of distance learning of students of universities of sport profile by means of information and communication technologies. Naukoviy chasopis NPU imeni M. P. Dragomanova. Vol. 11 (66)15, p. 12-16, 2015. (in Ukrainian)

[12] N. O. Belikova. Applied aspects of the use of information and communication technologies in the training of future specialists in physical education and sports. Visnyk Chernihivskoho Natsionalnoho Pedagogichnoho Universitetu. Seria: Pedagogichni Nauky. Phyzychne vychovannia i sport. Vol. 118(2), p. 21-24. 2014. (in Ukrainian)

[13] Yu. V. Dragnev. Informatization of professional education of the future teacher of physical culture. Pedagogy, psychology and medical-biological problems of physical education and sports. № 2, p. 33-35, 2012. (in Ukrainian)

[14] R. V. Klopov. Informatization of higher physical education. Teoria i metodyka phyzychnoho vychovannia. № 4, p. 3-7, 2007. (in Ukrainian)

[15] I. V. Liashenko. Prospects for the development of distance learning in high school. Narodna osvita. Vol. 1(25), 2015. [online]. Available: https://www.narodnaosvita.kiev.ua/?page_id=2682 Accessed on: May 23, 2018. (in Ukrainian)

[16] O. V. Otravenko. Influence of modern information technologies on the quality of professional training of future teachers of physical culture. Naukovo-metodychni osnovy vykorystannia informatsiinyh technologii v galuzi physychnoi cultury $i$ sporty. № 2, p. 70-73, 2018. [online]. Available: http://journals.uran.ua/itfcs/article/view/132522/128976 Accessed on: May 23, 2018. (in Ukrainian)

[17] O. M. Samoylenko, I. V. Batsurovs`ka, O. O. Samoylenko, N. A. Dotsenko. Implementation of the model for masters preparation to the educational and scientific activity in the conditions of massive open online courses. Informatsiini technologii $i$ zasoby navchannia. Vol. 64, № 2, p. 197-220. [online]. Available: https://journal.iitta.gov.ua/index.php/itlt/issue/view/93/showToc Accessed on: May 23, 2018. (in Ukrainian)

[18] A. V. Suschenko. Information and communication technologies and means of training in the training of future specialists in physical education and sports. Visnyk Zaporizhskoho natsionalnoho universitetu. Seria Phyzychne vychovannia $i$ sport. № 1 (7), p. 104-111, 2012. (in Ukrainian)

[19] Information technologies and teaching aids. Theory, methodology and practice of ICT use in education. [online]. Available: https://journal.iitta.gov.ua/index.php/itlt/index Accessed on: May 23, 2018. (in Ukrainian)

[20] Scientific and methodical bases of use of information technologies in the field of physical culture and sports. Collection of scientific works. [online]. Available: http://journals.uran.ua/itfcs Accessed on: May 20, 2018. (in Ukrainian; in English)

[21] Distance learning. ChNPU. [online]. Available: https://moodle.chnpu.edu.ua/course/index.php?categoryid=43 Accessed on: May 20, 2018. (in Ukrainian)

[22] Teachers of physical culture. Communal Educational Institution of Kyiv Regional Council "Kyiv Regional Institute of Postgraduate Education of Teachers". [online]. Available: https://www.xn--80aamewp7k6b.com.ua/karta-sajtu2/navchalno-metodychna-robota/dystantsijna-forma- navchannya/dystantsijni-kursy/vchyteli-fizychnoyi-kultury/ Accessed on: May 28, 2018. (in Ukrainian)

[23] Physical culture (distance course). Mukachiv Secondary School № 20 named after O. Dukhnovich. [online]. Available: http://20zoshmk.at.ua/load/dlja_uchniv/distancijne_navchannja/fizichna_kultura/23-1-0-116 Accessed on: May 28, 2018. (in Ukrainian)

[24] Physical Education. Distance Learning. [online]. Available: https://sites.google.com/site/pupilnvk/11-klas/fizicnakultura Accessed on: May 28, 2018. (in Ukrainian)

[25] N. O. Terentieva. Formation of new thinking in educational institutions: manual. Cherkasy, FOP Chabanenko Yu.A., 2018. 48 p. (in Ukrainian)

[26] N. O. Terentieva. Design of the discipline "Management in education, physical education and sports" for masters students. Visnyk Chernihivskoho Natsionalnoho Pedagogichnoho Universitetu. Seria: Pedagogichni Nauky. Vol. 144, p. 302-306, 2017. (in Ukrainian)

[27] Ukrainian Academy of Acmeology. All-Ukrainian public organization. [online]. Available: http://acmeology.org.ua Accessed on: May 20, 2018. (in Ukrainian)

\section{$(\mathrm{Cc}) \mathrm{BY}-\mathrm{NC}-\mathrm{SA}$}

This work is licensed under Creative Commons Attribution-NonCommercial-ShareAlike 4.0 International License. 